\title{
Who should be granted electoral rights at the state level?
}

\author{
Melina Duarte
}

Department of Philosophy, Faculty of Humanities, Social Sciences and Education UiT The Arctic University of Norway, melina.duarte@uit.no

DOI: http://dx.doi.org/10.5324/eip.v12i2.2411

(cc) BY

This is an open access article distributed under the terms of the Creative Commons Attribution 4.0 International License, which permits unrestricted use, distribution, and reproduction in any medium, provided the original author and source are credited.

This paper has a twofold aim in determining who should be granted electoral rights at the state level, one negative and another positive. The negative part deconstructs the link between state-level political membership and citizenship and contests naturalization procedures. This approach argues that naturalization procedures, when coercively used as a necessary condition for accessing electoral rights at the state level, are both inconsistent with liberal democratic ideals and an inexcusable practice in liberal democratic states. The positive part of the paper seeks to establish what - if not the acquisition of citizenship-could determine state-level political membership for non-citizens. In other words, it attempts to explain how and in what conditions noncitizens may become political members of a state without naturalizing. This approach considers the most prominent arguments that base state-level political membership on residency, i.e. residency as a legal status granted by the previous members of the community and residency as physical presence within a defined jurisdiction. It argues that, in a world of increasing human mobility across borders, while the former way of understanding residency might be too restrictive, the latter might be too banal to forge membership ties that form a political community. Domicile is the proposed alternative, introduced as a type of residency that is self-given and remains stable despite numerous changes of residency. Domicile is a legal term that indicates where a person officially registers her permanent home even when residing abroad. In sum, this is an argument against naturalization as the access door for electoral rights at the state level and in favor of defining membership in the political community based on domicile.

Keywords: citizenship; liberal democracy; naturalization; non-citizenship; popular sovereignty

\section{Introduction}

Electoral rights are rights to political participation that most notably include rights related to electing political representatives, participating in referendums, and being elected, should one wish to participate. ${ }^{1}$ These rights are considered to have intrinsic and instrumental value with respect to maintaining human dignity and are therefore recognized as human rights. Intrinsically, electoral rights are seen as fundamental to the exercise of human agency and autonomy and to the expression of equal worth. 
Instrumentally, they are considered essential to the preservation of other basic civil and political rights. The 1948 Universal Declaration of Human Rights (UDHR Art. 21), the International Covenant on Civil and Political Rights (ICCPR Art. 25), and other important international documents similarly advance the idea that everyone shall have the right and opportunity to vote, participate in politics, and be elected through genuine and periodic elections. This means that, at the least, all signatory states are committed to the promotion and protection of universal and equal suffrage. Universal and equal suffrage implies that, in granting these rights, there should be no distinction when it comes to "race, colour, sex, language, religion, political or other opinion, national or social origin, property, birth or other status" (see ICCPR, Art. 2). Liberal democratic states customarily limit this universal right according to personal traits such as age, cognitive abilities, criminal convictions (in some cases), and also according to collective traits such as political membership (Ziegler 2017, 4). All these restrictions are, to some extent, challengeable on different grounds, but here I will problematize only political membership. In this context, I will consider the case of cognitively able adults with no criminal records whose full membership within the political community at the state level is contested.

In practice, restricting electoral rights at the state level to members of the political community in most cases equals limiting these rights to citizens. ${ }^{2}$ Persons within a state's territory who are not citizens, however, are therefore unable to access electoral rights at the state level in their country of residency. This means that non-citizens are denied state-level membership in the political community in this sphere. Underlying this exclusionary practice is the notion that non-citizens are, per definition, political outsiders and that a self-governing community is rightfully empowered to exclude them from its electoral processes. According to this perspective, human rights are interpreted in a way such that even signatory states committed to universal suffrage have no obligation to allow non-citizens to vote, participate in referendums or stand as candidates in their host country, as long as they can contribute to ensure that noncitizens are able to exercise these rights elsewhere, such as in their country of origin. The 1985 UN Declaration on the Human Rights of Individuals Who are not Nationals of the Country in which They Live sets out the inalienable rights of non-citizens. These rights concern the rights to life; security; freedom from arbitrary arrest or detention; freedom of thought; privacy; constitute a family; retain language, culture and tradition; transfer money abroad and so on. They do not include any provision on electoral rights. Prolonged disenfranchisement of non-citizens from the political sphere can, however, impair integration and pose serious democratic challenges to the host country regarding the legitimacy of the state's public power. Therefore, even if we consider non-citizens as being excluded by default from political membership at the state level, there are reasons why this status should be examined in some cases.

Non-citizenship is a broad category that includes everyone within the territory of a state while having rights, a passport, and roots elsewhere or nowhere. From a legal perspective, they are permanent residents, temporary residents, refugees, irregular immigrants, stateless persons, and in some sense, visitors and transients. Clearly, not all non-citizens are outsiders to the same extent, nor are they regulated by the same rules. While it might sound reasonable to claim that visitors and transients should not be considered members of the statewide political community, the same reasoning should not be directly applied to other non-citizens who have established residency in a foreign state. Contrary to visitors and transients, non-citizen residents share the 
intention to stay for a prolonged amount of time in the host state. The concealed connection between time of residency and social integration provides prolonged residency in a foreign state with a moral meaning that might justify further entitlements for residents irrespective of citizenship (e.g. Carens 2010, Seglow 2009). Permanent residents are in this sense the strongest example of non-citizens whose 'outsiderness' in the community has become more tangential in terms of accessing some of the rights of citizens. In most liberal democracies, permanent residents have been granted civil and social rights, such as rights to ownership and alienation of property as well as rights to social security and welfare. In some of these states, such as the Scandinavian countries and the Netherlands, non-citizen permanent residents have been recognized as political members of the local community and granted electoral rights at subnational levels. This means that it is possible to become a member of the political community without being a citizen. However, even in these countries membership in the political community at the state level continues to be reserved for citizens.

Thus, in determining who should be granted electoral rights at the state level, it becomes crucial to understand the difference between political membership at the subnational and state levels that only requires citizenship for the latter. In other words, what is special about political membership at the state level that creates this apparently necessary link to citizenship? How is it that a non-citizen, who is recognized as a member of the political community at the subnational level, cannot have the same recognition at the state level? Why is residency per se not enough to establish someone's belonging to a political community at the state level? Of course, one can say that when non-citizen residents are recognized as members of the local political community and granted electoral rights at the subnational level, they have by then acquired a kind of local citizenship (see Kymlicka 2006, 139). However, citizenship in that sense comes neither with a passport nor with extra protection against deportation. Local citizenship can also be lost after an interruption of residency. As local and state citizenships refer to different sets of rights, I will reserve the term citizenship for referring to state/national citizenship. Whereas citizenship can signify a set of rights and obligations enjoyed equally by the members of the political community, it can also signify belonging to a national community, which is historically tied to nationhood and national identity (Kymlicka and Norman 1994, 353). To suppress or smother this parochial dimension of citizenship when theorizing seems not to remove its effective links to nationality, which often remain implicitly behind our current practices of membership control and exclusion. For example, even if ius soli (right of soil) is celebrated as an advancement of a denationalized form of citizenship, very few states, and none in the EU, adopt unconditional ius soli policies irrespective of ius sanguinis (right of blood) (Honohan 2010). To grant citizenship to foreigners in terms of ius domicilii (right of residence or domicile), these same states do require sufficient assimilation to community values (e.g. French community values, British values, Dutch values) - values that do not necessarily reflect only political allegiance. Naturalization, as the ritual of transforming the 'alien' into the 'natural', risks permitting and perhaps even reinforcing nationalizing practices (Kostakoupoulou 2008, 81). Even if it can be argued that its requirements have been gradually loosened by some states (despite also having been strengthened by other states following policy changes made after 9/11), naturalization still has a strong symbolic effect that constrains the relationship between mobile individuals 
and states in an archaic way. Whereas minimal knowledge of the language may sound like a reasonable requirement for naturalization, the UK has justified an increasing number of refusals since 2002 for not meeting "good character" requirements (different than absence of criminal records) (Blinder 2015, 2,7). The fear of not meeting such a criterion might also deter some non-citizen residents from applying for naturalization (Ryan 2008).

From this I assume that nationalism is what is keeping political membership at the state level tied to citizenship (Brubacker 1992, 31). Despite some conceptual transformations, citizenship remains a loaded status (Lægaard 2012). Political membership at the state level may still largely depend on pre-political connections among those who belong to the national community. Non-citizen residents can become members of the local political community based on prolonged residency, but residency is not enough to make them members of the political community at the state level; citizenship adds this "something else" which I assume to be membership in the national community. The problem with this is that making full political membership at the state level conditional on citizenship maintains and reinforces the link between political and a certain cultural membership, which is largely inconsistent with the liberal-democratic ideals of pluralism and tolerance.

With this in mind, this paper has a twofold aim, one negative and the other positive. The negative part will argue against collapsing state-level political membership with citizenship, for this alleged necessary link is precisely what makes naturalization a problem (Section 1). When naturalization is the only access door to electoral rights at the state level for non-citizens, it acquires coercive elements that are inconsistent with liberal democratic ideals (Section 1A). Furthermore, naturalization procedures that are unable to prevent social stratification and inequality of status and that potentially reinforce the divide between citizens and naturalized citizens are also inexcusable in liberal democratic states (Section 1B). The positive part of the paper will seek to establish what - if not the acquisition of citizenship -could determine state-level political membership for non-citizens. In other words, it will attempt to explain how and in what conditions non-citizens may become political members of a state without naturalizing (Section 2). I will consider the most prominent arguments that base state-level political membership on residency, i.e. residency as a legal status granted by the previous members of the community (e.g. status of permanent or temporary resident) and residency as physical presence within a defined jurisdiction. I argue that, in a world of increasing human mobility across borders, while the former way of understanding residency might be too restrictive, the latter might be to banal to forge membership ties that form a political community. Domicile is the proposed alternative, introduced as a type of residency that is self-given and remains stable despite numerous changes of residency. Domicile is a legal term that indicates where a person officially registers her permanent home even when residing abroad. In sum, this is an argument against naturalization as the access door for electoral rights at the state level and in favor of defining membership in the political community based on domicile.

\section{When is naturalization a problem?}

Naturalization is the legal act or process that gives non-citizens the status of citizenship. Non-citizens who meet the requirements can become naturalized citizens. This can happen automatically, as in the case of foreign-born children 
adopted internationally, or through the submission and approval of an application. For a non-citizen resident, naturalization can be both the realization of a dream or the makings of a nightmare (see Aptekar 2015; Byrne 2014). For those who see it as the realization of a dream, the new passport is received with pride, and the citizenship ceremony emerges as a symbol of the recognition of their efforts in being accepted into the new community. After all, although the degree of difficulty varies significantly from country to country, it is usually not easy to meet the requirements for naturalization. To be eligible to naturalize, non-citizens must usually meet the following formal requirements: document a prolonged and continuous residency in the country in which they have applied for citizenship; not have been convicted of a serious crime; (in some cases) prove that they are of "good character"; be economically self-dependent; (in some cases) abdicate their previous citizenship(s); pay an application fee; and also prove sufficient knowledge of language, history, laws, and culture by attending official courses and/or taking official tests. When applicants successfully accomplish all of these feats, their new status empowers former noncitizens with a sense of fulfilment and feelings of equality of worth, dignity, and belonging. Citizenship ceremonies indeed tend to be beautiful. Everyone dresses in their best attire. The new citizens are asked to swear allegiance to the royal family and/or to the country, promising to be loyal subjects and respect the law, human rights, and democracy. After that, they are welcomed into the new community. Naturalization is an end in itself for these individuals and facilitates a meaningful transition to a new and desirable status.

For those who see the process as a nightmare, on the other hand, naturalization appears as an attempt to eliminate the otherness instead of integrating the differences. The new passport can even become a source of shame, bringing to the fore feelings of betrayal of their roots or disconnecting them from their past (especially when dual citizenship is not permitted). It can also produce feelings of misappropriation of somebody else's collective identity. Although citizenship ceremonies are usually not mandatory, they might still be interpreted as symbolic conformity to a certain mainstream that constrains the relationship between individuals and states. Thus, instead of bringing a sense of accomplishment, naturalization brings for these individuals feelings of loss and of disrespect and disregard for who they were before acquiring the new status. Naturalization demands standardizing their former plurality and proving their worthiness and loyalty on a very personal and subjective level. If they have to pledge loyalty, for example, it is because they were not considered loyal before, simply because they were born in a different country. These individuals do not view naturalization an end in itself, but as a means to acquire certain rights without which their subjection to the public authority would remain unilateral. In fact, many non-citizen residents who meet the requirements for naturalization opt to relinquish the their state-level electoral rights in their country of residency because the costs of naturalization are psychologically excessive (Ryan 2008). They regard naturalization as a problem if it is a condition that they must meet in order to access electoral rights at the state level. This means that they might not want to submit to the process, but end up accepting it in order to achieve other goals that they consider more important. Naturalization, in this sense, acquires a coercive element.

Of course, the two cases mentioned above do not exhaust all the possible meanings of naturalization for non-citizens. Some individuals feel confused (skeptical) and others absolutely do not care whether they have to naturalize or not (cynical). While 
the former might suspend or delay judgment, the latter might simply accept being naturalized if this brings them more benefits than burdens; for the latter a passport is just a piece of paper and a citizenship ceremony is just a party. Considering all these differences when it comes to conceptualizing naturalization, the argument developed in this paper cannot address them all. For example, I see no reason why naturalization should not be an option for those who desire the new status or for those who do not really care. This argument does not advocate for abolishing naturalization procedures for every non-citizen resident, but only naturalization as a necessary condition to the access state-level electoral rights. In other words, it advocates for separating citizenship from membership in the political community at the state level as a way to eliminate the problematic coercive element of naturalization. Whether citizenship should be a sufficient condition to determine one's membership in a political community at the state level is a question that is beyond the scope of this paper. By advocating for the detachment of citizenship from political membership at the state level, the paper argues that citizenship should not be a necessary condition for determining one's political membership at the state level and that non-citizens should therefore not be coerced to naturalize in order to be able to access electoral rights at that level.

One could first argue that because non-citizen residents who meet the naturalization requirements have a choice, naturalization is not really coercive in the sense that no violence or force is used to impose a certain outcome. Non-citizen residents can choose whether to naturalize and be granted electoral rights at the state level or to keep their status as non-citizens and cede these rights. It is a trade-off and they can in principle choose to be either in or out. In that sense, all we would need to care about in order to secure social justice for non-citizens is whether they are offered fair and transparent procedures to become a citizen if that is what they hope to achieve. Opting for this route would not allow us to eliminate the potential coercive element of naturalization, however. Based on Nozick's influential understanding of coercion (Nozick 1969, 441-445), naturalization could perhaps qualify as coercion as a conditional threat, in which the appearance of 'choice' is a crucial element. Coercion via threat means that, despite being able to choose, the psychological costs involved in the decision are so high that the person is discouraged from exercising her will. If naturalization is a coercive threat in Nozick's sense, it must meet the following conditions:

(1) A state aims to keep non-citizen residents from having electoral rights at the state level.

(2) A state claims that electoral rights are a privilege of the citizens.

(3) The state's claim indicates that if non-citizens want to have electoral rights at the state level, they must become citizens.

(4) Some non-citizens do not wish to become citizens because, in practice, this means that they will also have to aim to become nationals.

(5) As a result, some of these non-citizens do not naturalize and consequently are not granted electoral rights at the state level.

(6) Part of the non-citizens' reason for not naturalizing and not acquiring electoral rights at the state level is due to the fact that, in order to do that, they must also strive to become nationals.

It seems that Nozick's approach would perhaps classify naturalization as a case of coercion via threat, but only for those who opt out of it. Non-citizen residents who 
accept the costs of naturalization despite their reluctance would then not be considered as having been coerced. This requirement is usually called Nozick's 'success condition'. Alongside the critics of Nozick's 'success condition' (e.g. Carr 1988), I subscribe to the view that coercion via threat can be said to apply even in a case where someone has a (perverse) incentive not to perform certain acts that they would otherwise perform. In either case, naturalization would be coercive for some and felt as coercive for others who find its demands too high. For the case advanced here, it is enough to show that naturalization has a coercive element that might hinder some non-citizen residents from accessing electoral rights at the state level or make then reluctant to access these rights.

Coercion is in principle wrong, but sometimes justifiable. That is why it is not enough to show that naturalization, as a condition for political membership at the state level, is potentially coercive in order to advocate its abolition. It must be shown why this kind of coercion is also an unjustifiable practice. In a first step, I will argue that naturalization - in the terms defined here of implying a kind of coercion - is inconsistent with liberal democratic ideals. However, this still allows for the possibility of 'excusing' liberal democracies for perpetuating a harmful practice in order to prevent a greater harm - a lesser evil, so to speak. In a second step, I will argue that naturalization procedures applied as a condition for granting electoral rights at the state level do not achieve the goal of preventing a greater harm and are therefore inexcusable as well.

\section{A) Naturalization as the access door to electoral rights at the state level is inconsistent with liberal democratic ideals.}

In the context of liberal democracies - states committed to promoting and protecting human rights, pluralism and diversity, and universal suffrage - naturalization as the access door to political rights at the state level remains a controversial procedure (e.g. Joppke 2010, 1,11; Michalowski 2010, 2; Groenendijk and van Oers 2010, 3; Carens 2010a, 5; Kostakopoulou 2010, 6; Orgad 2010, 7). This is because, despite the advancements of a liberal conception of citizenship towards the detachment from nationalism, citizenship is still a loaded status in which membership in a political community might still depend on the pre-political links among those who already belong to a national community (Viola 2004, 521). Belonging to a pre-political community is usually originally assigned by birth. Birthplace combined with ascendancy, or ascendancy alone, are currently taken as sufficient conditions for determining someone's inclusion in a pre-political community. In the absence of restrictions concerning age, cognitive ability, and criminal records, members of the pre-political community, as citizens from the very start, automatically become members of the political community. In this context, both birthplace combined with ascendency and ascendency alone are understood as meaningful signs of continuity within historically stable communities where individuals share a special connection to one another (e.g. Walzer 2008; Miller 2008). This special connection can be expressed in terms of common values, common language and common culture. It can also be more or less restricted to some kind of unity with differing degrees of tolerance and diversity. All of these connections, when relying on blood and soil ties (territoriality, nationality, and history), still seem to resort, even if in different degrees, to a certain type of nationalism. The native-born are undoubtedly national 
citizens and most of them have electoral rights at the state level even when residing abroad.

For non-citizens, things are clearly different. Before they are entitled to become political members of the new community, non-citizens somehow have to acquire membership to a pre-political community though a different channel. Since noncitizens may not meet these two original conditions, they lack the initial special ties to the members of their new community. They can only acquire membership to a prepolitical community when these ties are forged. Residency is one way to acquire membership in a pre-political community. Stronger claims are generated with prolonged residency and when the residency is legal. This type of pre-political membership is often called 'social membership' and comes with civil and social rights, but not with full political rights at the state level. Since being a social member means that the non-citizen is sufficiently operative and connected to the new community, some will argue that social membership should entitle the non-citizen to political membership even when the residency was classified as "irregular" (Carens 2013, 129157). For legal permanent residents, a few liberal democratic states recognize this claim at the local level, although few recognize it at the state level (see cases and conditions in footnote 3 ). In order to acquire full political membership at the state level, one must in most cases acquire citizenship first, if not by birth, then by naturalization.

Some would say that acquiring a new citizenship signals a commitment to the new community that is based on recent connections and on the promise of future special connections, instead of being based on special connections through previous generations. Naturalization then symbolically fills the gap left by the lack of meeting the conditions of birthplace and ascendancy (e.g. Carens 2013; Walzer 2008). It presents itself as an experience of being reborn from non-biological parents, whether one keeps in contact with the biological parents or not. Liberal democracies would in this sense then be justified in requiring non-citizens to naturalize in order to grant them full political rights at the state level, as long as naturalization procedures were transparent, not unfairly demanding, and not exclusive of specific groups. From this perspective, naturalization is supposed to act as both an inclusive and exclusive tool, separating resident aliens who are accepted as full political members at the state level from those who are not, and setting the alleged necessary conditions for democracy of having a bounded demos with self-governing rights. Citizenship in this sense still works as the determinant condition for full political membership at the state level and functions as a mark of an exclusive membership that is presented as being a necessary condition for democracy (e.g. Benhabib 2011, 140-44; 2004, 45). Political membership requires borders, democracy requires a bounded demos, and citizenship demarks who is in and who is out. According to this approach, all citizens and citizen residents should have electoral rights in their state of citizenship and be able to exclusively shape the laws by which they are governed. In this setting, different rights and obligations emerge for non-citizens. Self-governing rights suggest states have a duty to open naturalization channels for distributing citizenship to those already accepted as pre-political members of the new community, such as permanent residents. At the same time, states have the right to select which of them will become citizens by naturalization and which will not. Non-citizens in this scenario must first acquire citizenship in order to be granted electoral rights at the state level. This suggests that something incompatible with liberal democratic ideals would emerge 
only if naturalization procedures aim to eliminate pluralism and diversity (i.e. demand high levels of conformation), impose unreasonable conditions and reject naturalization applications on dubious or unjustifiable grounds. Apart from that, naturalization in itself would not necessarily be seen as a problem. Imposing naturalization as a condition for granting electoral rights would serve as the necessary democratic delimitation to liberalism and through this reasoning, its practice in liberal democracies would be 'sanctioned'.

This approach is however based on a disputed view of what democracy in liberal democracies entails. Influential rebuttals of this thesis (e.g. Dahl 1989; Goodin 2007; Abizadeh 2008) have shown that democracy, in the sense of popular sovereignty, might actually not necessitate borders in the sense of requiring a pre-bounded demos formed by citizens with the exclusive right to determine membership. Instead, everyone who is subjected to, affected by or coerced by a public law should be able to have a say on it. This would in principle include both citizens and non-citizens to the extent that the conditions above are met. Non-citizens who are social members of the pre-political community would acquire electoral rights at the state level and be able to decide whether a train station should be built in front of their house or whether a greater portion of the state's budget should be invested in education. At the same time, non-citizens living abroad should also have a say in policies that aim to exclude them from the territory in the first place. Certainly, these theories - whether based on subjection, coercion or affected interests - have very different implications, particularly as concerns the question of a demos' composition in international settings. However, since we are discussing electoral rights at the state level for noncitizen residents without questioning electoral rights for expatriates or foreigners, we do not need to go into detail on the differences between them. We can rather rely on a general appeal to the principle of popular sovereignty based on a single aspect that stresses the need for a reciprocal, bilateral, dynamic interconnection or interdependence between ruler and ruled. By committing to this principle of democracy concerning state-level electoral rights for non-citizen residents, we gain a conceptualization of a demos comprising both citizens and non-citizens that is compatible with liberal democratic ideals.

For illustrative purposes, imagine a state composed of citizens and non-citizens as virtually every state now is. The first thing that has to be clear is that when one claims that democracy needs borders, all that can be derived from that initially is that democracy needs jurisdictions. Whether or not citizens have the right to exclude noncitizens from political membership within these jurisdictions is as yet undetermined. Next we must ask what rationale citizens could use to give them the right to exclude non-citizens from political membership within such jurisdictions. Given that jurisdictions are the institutions with the official power to rule people within a certain region, in the context of liberal democracies, the power exercised over the people under these jurisdictions must be justified and legitimated.

Liberal democracies are distinct from autocracies particularly when it comes to how they justify the exercise of power over people. While those in charge in an autocracy unilaterally impose power over the people, in liberal democracies power must be mediated through just institutions and laws and legitimated through participation of the subjects in shaping these institutions and laws in a genuinely equal manner. It would be inconceivable nowadays for a liberal democracy to restrict participation based on gender or race, for example. If the citizens and non-citizens 
who comprise a jurisdiction respect its set of rules, a demos composed only of citizens would by definition be autocratic and therefore inconsistent with liberal democratic principles. This is because, if non-citizens respond primarily to a set of rules in a determined jurisdiction, then accepting the very principle that intends to justify their exclusion (i.e. the principle of popular sovereignty and its corollary principle of selfdetermination) actually leads to the need to include them in the default position. Thus, as with gender and race, it becomes inconceivable to exclude non-citizen residents from full and equal political membership at the state level, given that they respond to the same set of laws as citizens. As such, the principle of popular sovereignty would require that they have an equal right to shape those laws.

Several objections can be raised against this position. However, as contingent objections, none of them seems strong enough to justify excluding non-citizen residents from the default position of full and equal political membership at the state level. First, it could be argued that citizens and non-citizen residents do not respond to exactly the same set of laws within a jurisdiction, and therefore excluding noncitizens from political membership at the state level would be justifiable without infringing on the principle of popular sovereignty. Non-citizens might, for example, have tax exemptions and might not be subjected to forced conscription. Regarding taxation, this objection ceases to be relevant when tax exemptions are applicable only after the first years of residency in the new country. Further reductions aiming at avoiding double taxation are also open to citizens who happen to pay taxes abroad. Regarding forced conscription, this objection ceases to be relevant when voluntary recruitment or recruitment that includes both citizens and non-citizens becomes the norm. Second, it can be argued that if everybody who is responsive to the public law must have a say in it, this would suggest that even visitors and transients should acquire political rights at the state level. Visitors and transients, however, are only required to comply with simple rules of conduct while in loco, such as traffic rules. The submission is limited and ceases once they travel back home. A third objection would be an attempt to reclaim the principle of popular sovereignty for one predefined people. It could then be argued that the principle of popular sovereignty applies for 'The People,' and 'The People' do not comprise those who are responsive to a shared set of public laws but are a group sharing history, culture, language and special commitments to one another. In this case, this is the same as saying that 'The People' consist of nationals. But if 'The People' are pre-defined by nationals, the constitution of 'The People' cannot be said to be democratic.

\section{B) Naturalization practices are inexcusable}

Considering the argument above, I expect by now to have shown that coercing noncitizens to naturalize in order to acquire electoral rights at the state level is inconsistent with liberal democratic ideals. This view rests on the idea that democracy implies popular sovereignty for all those responsive to a certain set of public laws and policies. The fact that this is inconsistent, however, does not show that making use of naturalization practices as the condition to the distribution of electoral rights at the state level is also inexcusable in practice. It is, for example, inconsistent with my usual behavior and values to use violence against my child in order to discipline her. Every day, however, she tries to run towards the road as we are walking to her kindergarten. In order to avoid having her be hit by a car, I have to hold her hand and arm very firmly and pull her back towards the pedestrian path against her will. Her hand and 
arm become red and she cries uncontrollably for several minutes. Although the use of violence against my child is incoherent with my overall behavior and values, it seems that I am somehow excused for using violence in such a case as it prevents greater harm befalling my child. I must make a choice between a red arm and lots of crying versus letting her be hit by a car. Naturalization procedures could perhaps be excused in the same way. Consequently, in order to conclude the negative part of the argument against coercive naturalization practices, it remains to examine whether the reliance on naturalization practices for granting access to electoral rights at the state level is, besides being inconsistent, also inexcusable.

According to one perspective, naturalization could be seen as a particular harm inflicted on someone in order to prevent a greater harm. Coercing non-citizens to naturalize in order to grant them electoral rights at the state level might be said to have the effect of preventing social stratification and unequal status within the state. If non-citizens are coerced to naturalize, this would then serve the purpose of finally turning them into equal members of society. Naturalization would eliminate the division between citizens and non-citizen permanent residents within a political community, as they would all be seen as equal members, irrespective of origin. This would strengthen social cohesion and finally fully integrate non-citizens into the new community.

The problem with this view, however, is that it might be a romanticized view of what naturalization can de facto promote. In practice, if people perceive that naturalization does not grant 'citizenship' in the full sense, the category of naturalized citizens could be devalued into a kind of second-class citizenship. So although naturalized citizens do acquire equal legal and political status, naturalization might not change the meaning of citizenship itself (Lægaard 2012). Citizenship is indeed a very ambiguous and dynamic concept that has historically justified inclusionary as well as exclusionary practices. It has unified persons from different backgrounds, including social class, status, gender, and religious beliefs, but it has also created a divide between insiders and outsiders in a way that even made it possible to marginalize long-term residents and naturalized citizens within the same country. Although a liberal conception might hold that citizenship denotes nothing more than legal and political membership that comes with rights and corresponding duties, this ideal has not yet been realized. In practice, citizenship has not yet been fully denationalized. As such, membership to a pre-political community pre-defined by birth and ascendancy is still embedded in the idea of citizenship. No naturalization procedure seems capable of producing a citizenship status that promotes true equality for national and naturalized citizens. This is because, despite the best of intentions, naturalization is usually incapable of forging someone's belonging into a "community of character". If this were possible, it would mean that naturalization procedures were demanding too high of a level of conformation and ignoring the commitment to values of pluralism, diversity and tolerance, and the denationalization of political membership at the state level that follows from that. Thus, naturalization poses a problem both ways.

In summary, if a perception exists that naturalized citizens are not real citizens, and enough evidence can be found to show that this is at least partially the case (e.g. Rosales 2013, 47-50), naturalization procedures do not accomplish their designated task of promoting integration and equality. This means that these practices fail to prevent a greater harm and can potentially even cause more harm by feeding an idea 
of uniformity that is at the moment unachievable. As long as citizenship remains a signifier of membership within a "community of character" practice, naturalization will be unable to forge equality. Thus, naturalization becomes inexcusable if it fails to prevent the greater harm of social stratification and inequality inside a political community.

\section{Electoral rights at the state level based on domicile}

By now, I hope to have shown that naturalization procedures, when coercively used as a necessary condition to the distribution of electoral rights at the state level, is not only inconsistent with liberal democratic ideals, but also an inexcusable practice in liberal democratic states. This gives me enough reason to conclude that such practices should be abolished in this context. Abolishing naturalization practices from this context implies removing citizenship from the role of being a necessary condition to full and equal political membership at the state level and, consequently, detaching citizenship from electoral rights at this level. This requires rejecting not only positions that give special weight and meaning to citizenship in terms of constituting the political community (e.g. Miller 2008; Walzer 2008), but also the more hybrid positions of an easy or automatic path to naturalization after a certain period of residency in the host country (e.g. Carens 2010, Rubio-Marin 1998). Citizens and non-citizens qua non-citizens should in principle be able to become political members of a state and have electoral rights at this level if they are responsive to the same set of laws and policies. In order to finalize the argument in a positive way, it remains to show what would then define political membership at the state level for non-citizens, if not citizenship. In other words, how would a non-citizen be included in the political community at the state level if not through naturalization?

Non-citizens could become members of a political community through residency, or more specifically, through what residency entails. Let us start by going back to the fundamental democratic principle of popular sovereignty in the general sense we defined earlier. Recall that according to this principle all persons who are responsive to a certain set of laws and policies should be able to participate in shaping it. This principle appears in many forms under an expansion of the Aristotelian general idea of "rule while being ruled" and can emphasize subjection to the law (Dahl, 1989), compliance with the law (Rawls 1971, 221), being affected by the law (Goodin 2007) or being coerced by the law (Abizadeh 2008, Lópes-Guerra 2005). The important aspect of this principle that I want to highlight here is in its form. The content might change and present us with different suggestions on how to define the demos as mentioned above, but the form is constant in regard to the need for a dynamic interconnection between ruler and ruled in order to achieve efficacy and legitimacy in a democracy. Whereas Aristotle's democracy was compatible with excluding certain classes of people, such as such as women and slaves, from it - i.e. being ruled without having the right to rule - the latest expansions of this idea seem to be approaching an understanding that democracy is only democratic if it is for all. This means that this principle might be relevant not only for determining how the decisions should be taken inside of a pre-defined political community, but also for determining who should constitute such a community. According to these latest views emphasizing the importance of the principle in determining the constitution of a political community, everyone who is responsive to the law should then be able to have a say on it. If citizens and non-citizens are responsive to the same set of laws and 
policies, it follows that non-citizens should also be part of the political community and, as such, be able to participate in shaping these laws and policies in equal measure.

From there, the interpretation of what it means "to be responsive to a set of laws and policies" will determine whether all or some non-citizens should acquire the right to have a say in it. Being responsive to a set of laws and policies means being part of a certain jurisdiction. Because jurisdictions are mainly, though not exclusively, territorial and concentrated, in a sense, within the state borders, residency acquires the capacity to determine who should be a member of the political community. Do all non-citizen residents of a certain jurisdiction then become responsive to the laws and policies, as do citizens? We already saw that visitors and transients do not, since their responsiveness to the law is limited to rules of conduct that cease once they leave the territory. If this is the case, they perhaps should not be said to be responsive to the laws that citizens are. (A tenant, for example, might have to comply with the house rules during the period of their stay and not wear shoes or listen to loud music while inside the house. But if the tenant gets attached to the house and ends up by buying a share of it, becoming responsible for paying property taxes, renovation and other bills, they can suggest a change in the house rules. For this to happen, they must become an owner and have something to lose should the house start to deteriorate). We also already saw that permanent residents have the strongest claims for political equality at the state level, because they are able to validate their ties and commitments to the continuity of such a community. In most cases this validation happens after a prolonged period of residency in which these non-citizens are expected to have created special ties with the community. They become able to show that their future is in line with that of the community. In other cases, depending on the policies of particular states, this validation can also be granted after signs of commitment to the community are shown, independent of residency. This is the case for entrepreneurs investing a great sum of money in the country, highly skilled workers investing expertise or spouses investing emotional commitment to the family. In line with that, some will argue that only permanent residents are in a position to become full political members of a political community at the state level because only they have settled in the community in such a way that they establish a relationship of dependency to the community to the same extent as national citizens (Rubio-Marin 1998).

Some wish to extend electoral rights at the state level for temporary residents, because the qualifications attributed to permanent residents regarding ties and commitments to the new community could be also attributed to temporary residents (Beckman 2008). More importantly, all of them would in principle be equally responsive to the laws and policies ruling this territory, supporting the belief that the democratic principle of popular sovereignty does not allow for a differentiation between permanent and temporary residents since (Beckman 2008, Lópes-Guerra 2005). This interpretation of the democratic principle removes the emphasis on time of residency and stresses the place of residency, which leads to a view that not only are there no reasons for not enfranchising irregular immigrants, but also that there are no reasons why they should not be rapidly enfranchised (Angell \& Huseby 2017). Although these interpretations of what it means to be "responsive to a set of laws and policies" have a great deal of merit in terms of showing that democratically constituting the demos matters when it comes to defining a democracy and that time of previous residency might not matter, they may be overemphasizing the role that 
place of residency plays in constituting the demos. The risk of this approach is that in a globalized world of mobile individuals, place of residency might become too banal to determine one's political membership in a political community. Overemphasizing place of residency may overlook the implications of the fact that domestic laws have the potential to subject, affect, or coerce someone across jurisdictional and geographical borders, making place of residency somewhat arbitrary.

In the end, residency is both too strong and too weak for determining political membership within a political community. Understood as a legal term (e.g. permanent resident, temporary resident), residency may be too strong not only because it allows for arbitrary classifications among residents, but also because legal residency is a permit that is distributed by previous members of the community. Moreover, relying on such distribution would allow for a non-democratic constitution of the demos. Understood as the physical presence within a certain jurisdiction, residency may be too weak and unable to create the necessary ties to forge membership in a meaningful sense. Political membership is not a mere aggregate of individuals who happen to live within the same jurisdiction, but an understanding of being part of a group and becoming responsible for the wellbeing of the other members of this community in addition to their own. Political membership goes beyond sharing a space and requires creating, keeping, and sustaining this space together.

In contrast to these views, I argue that political membership at the state level should be based on domicile. Domicile is a particular type of residency that is neither reduced to physical presence within a determined territory nor to a legal status granted by the previous members of the community. Domicile is the place where a person legally registers their permanent home. This may initially be tied to physical presence, but it does not cease when the place of residency changes temporarily. In this sense, a person would have electoral rights in their country of domicile, i.e. in the country where they register the address of their permanent home. The advantage is that this is more coherent with the democratic principle of political members being those who are subjected/affected/coerced by the law. Mobile individuals can be physically present within a jurisdiction for a period of time and be responsive to the set of laws and policies there for that period. However, if individuals are granted electoral rights at the state level based on domicile, they are granted the right to shape the future and might move away before being affected by the laws and policies they helped to shape, since laws and policies are made to be stable and difficult to change. If individuals vote and leave the country, their vote is imposed on the remaining residents. This does not succeed at making the composition of the demos more democratic. Mobile individuals are subjected to rules of conduct, but until their residency includes responsibility and commitment to the wellbeing of the community, they cannot be said to be political members. Since electoral rights shape the future, past or present residency must not matter. To register a domicile in a certain jurisdiction would then signal such commitment for the future. By registering a domicile in a certain jurisdiction instead of another, a person consents to being excluded from the decision-making processes of the jurisdictions to which she is not primarily committed. Being collaterally affected by the ruling of external jurisdictions only then becomes acceptable to her. Political membership and the borders of democracy are, according to this approach, defined when the demos is constituted through an act of inclusion that promotes self-exclusion. 
Countering this view is the objection that basing political membership on domicile is not fully in line with the principle of popular sovereignty, when domicile means the place where a person legally registers their permanent home even when temporarily leaving abroad. First, it could be argued that a person living abroad is responsive to the set of laws and policies there, and that is where they should be able to shape laws and policies. But, as we saw, although physical presence makes someone responsive to the set of laws and policies in loco, this is limited to rules of conduct and ceases when the person moves to another jurisdiction. What seems to matter in determining political membership is not where a person physically resides, but where they are a legal person. Where one is located as a body can be accidental, while where one is as a legal person can be the result of a choice. Second, it could be argued that basing political membership on domicile violates the principle of popular sovereignty, because the act of becoming a member was not a function of a decision made by the members and non-members, but an imposition of the aspiring member over the members. The line that defines the constitution of the demos needs to be drawn somewhere. The principle must be constrained by its feasibility to implement, and it is simply not feasible to consult members and non-members every time someone wants to become a member of the political community. The challenge is to find a way of drawing the line that would best approach the principle. Drawing the line based on physical presence in a territory overlooks the facts that borders are controlled and that domestic laws and policies might subject, affect, or coerce people who are outside the jurisdictional borders of a state. The alternative - i.e. drawing the line based on domicile - introduces a compromise that takes these two issues into account. Basing political membership at the state level in domicile is, in the terms defined here, an imposition of membership from non-members over members. This imposition, however, holds new members responsible for investing in the success of the community and caring for the wellbeing of its members (since they themselves become members of it). It also requires new members to deliberately accept exclusion of membership in other jurisdictions, which might finally make unilateral subjection to cross-jurisdictional ruling acceptable.

\section{Conclusion}

This paper had a twofold aim in determining who should be granted electoral rights at the state level, one negative and another positive. Since electoral rights at the state level are still reserved for citizens in most states, the negative part of the paper consisted of deconstructing the links that seem to necessarily link political membership at the state level to citizenship. I then contested naturalization procedures as the access door to electoral rights at that level. This argument showed that naturalization procedures, when coercively used as a necessary condition for the access to electoral rights at the state level, are both inconsistent with liberal democratic ideals and an inexcusable practice in liberal democratic states. This is because electoral rights at the state level should be granted to all members of the political community. Following the bilateral aspect of the democratic principle of popular sovereignty, citizens and non-citizens qua non-citizens could become members of the political community as long as they are all equally responsive to the same set of laws and policies. I concluded that naturalization practices should thus be abolished within this context. This conclusion exposed a gap that needed to be filled by a positive proposal. The positive part consisted in finding an alternative to 
naturalization to determine the inclusion of non-citizens in the political community at the state level. I considered prominent views that attempt to base political membership on residency, two examples of which I examined: one emphasizing the meaning of legal status (e.g. permanent residents, temporary residents) and another emphasizing physical presence in a defined jurisdiction. I argued that both interpretations were unable to capture the essence of what it means to be a member of a political community, proposing that this determination should instead be based on domicile.

Domicile was defined as a type of residency that is neither reduced to a legal status nor to physical presence. Grounding political membership at the state level on this type of residency has several advantages in relation to the previous two approaches, since it combines relevant elements from both at the same time as it avoids their weaknesses. Domicile, in the way defined here, is a legal term denoting a type of legal residency in the same way that permanent residency and temporary residency do. However, it is not based on an arbitrary classification of different types of residency that assumes to correctly capture the temporality of residency and the ties that derive from that. Nor is domicile based on a status granted by the previous members of the political community, which would result in creating a barrier for legal residency instead of providing access to political membership in the community for non-citizens. Domicile is the place where a person legally registers their permanent home. This act of 'registering a permanent home' ties an individual's success to their new community and creates a committed membership that is not a mere aggregate of individuals within a certain space. Domicile can also be based on physical presence in a specified jurisdiction, which brings to light the advantages of making past residency irrelevant in signaling future commitments but it also makes present residency equally irrelevant. Domicile is the place where a person's permanent home is registered even when temporarily living abroad, which makes a domicile more suitable for responding to the challenges brought on by a globalized world of increasing human cross-border mobility. If mobile individuals were granted electoral rights based on their present physical location, they might move away before bearing the consequences of their votes. This would, in a sense, be as incoherent with the democratic principle of popular sovereignty as not allowing non-citizens to vote at all, with the incoherence breaking the other way.

My conclusion of the overarching argument was that political membership at the state level should be based on domicile. Political membership at the state level should not be reduced to citizenship, and naturalization procedures as the access door to electoral rights at the state level should be abolished. This way forward should allow citizens and non-citizens qua non-citizens to become political members and access electoral rights at the state level as long as they are domiciliated in such a jurisdiction.

\section{Acknowledgements}

This paper was written in connection with the projects "Globalization, Cosmopolitanism, and Migration" (financed by the Swedish Research Council 20162017) and "Globalizing Minority Rights" (financed by the Research Council of Norway 2016-2020). The author is grateful for the comments and suggestions given by M. S. Egan, J.H. Alnes, A. Alvarez, A. Vitikainen, M. Woons, M. Ronzoni and S. Lægaard, as well as the three anonymous reviewers of a previous version of this paper. 


\section{Notes}

${ }^{1}$ Political participation can also be seen as a duty. Framing political participation as a duty instead of a right would, however, require a different argument and is therefore not developed in this paper. Instead of arguing that some non-citizens should have the right to full political participation at the state level, the argument would have to be that some non-citizens would be obligated to participate. See e.g. De Schutter and Ypi 2015.

${ }^{2}$ Non-citizen residents have voting rights at the state level after 5 years of continuous legal residency in Chile and Ecuador and after 15 years in Uruguay, though they do not have the right to stand as candidates. Brazilians have full electoral rights in Portugal provided that they have resided there for at least 3 years prior to the election. Irish and commonwealth citizens residing in the UK and who have or do not require an "Indefinite Leave to Remain" in the country also have full electoral rights in the UK. In Australia, non-citizen residents who are members of the British Crown and have been continuously enrolled since 26/01/1984 can vote at the state level, but not stand as a candidate. British citizens residing in the Republic of Ireland can vote at the state level, but not stand as candidates. In New Zealand, partial enfranchisement occurs after one year of continuous residency for all those who have not been convicted of certain offences, have not been previously deported, do not represent a risk to national security, or are not on a temporary permit. Non-citizen residents in New Zealand cannot stand as candidates. See more at Waldrauch (2005); GLOBALCIT (2017).

\section{References}

Abizadeh, A. (2008). Democratic theory and border coercion: no right to unilaterally control your own borders. Political theory, 36(1), 37-65. https://doi.org/10.1177/ 0090591707310090

Angell, K., \& Huseby, R. (2017). Should Irregular Immigrants Be (Rapidly) Enfranchised?. Political Research Quarterly, 70(2), 363-373. https://doi.org/ $10.1177 / 1065912917695188$

Aptekar, S. (2015). The road to citizenship: what naturalization means for immigrants and the United States. Rutgers University Press.

Bauböck, R. (2005). Expansive citizenship-voting beyond territory and membership. PS: Political Science \& Politics, 38(4), 683-687. https://doi.org/ $10.1017 /$ S1049096505050341

Beckman, L. (2012). Is Residence Special? Democracy in the Age of Migration and Human Mobility. In Beckman, L. and Erman, E. eds. Territories of Citizenship. Palgrave Macmillan, London. 18-39.

Beckman, L. (2008). Who Should Vote? Conceptualizing Universal Suffrage in Studies of Democracy. Democratisation, 15(1), 29-48. https://doi.org/10.1080/ 13510340701768091

Beckman, L. (2013). Irregular migration and democracy: the case for inclusion. Citizenship Studies, 17(1), 48-60. https://doi.org/10.1080/13621025. 2012.669964

Benhabib, S. (2013). Dignity in adversity: Human rights in troubled times. Polity Press. 
Benhabib, S. (2004). The rights of others: Aliens, residents, and citizens (Vol. 5). Cambridge University Press.

Blinder, S. (2015). Naturalisation as a British citizen: Concepts and trends. Migration Observatory Briefing. Oxford: University of Oxford. Available at https://migrationobservatory.ox.ac.uk/resources/briefings/naturalisation-as-abritish-citizen-concepts-and-trends/. Last updated: 03 August 2018.

Brubaker, R., \& Cooper, F. (2000). Beyond “identity". Theory and society, 29(1), 1-47. https://doi.org/10.1023/A:1007068714468

Brubaker, R. (2009). Citizenship and nationhood in France and Germany. Harvard University Press.

Byrne, B. (2014). Making citizens: Public rituals and personal journeys to citizenship. The Palgrave Macmillan.

Carens, J. (2013). The Ethics of Immigration. Oxford University Press.

Carens, J. (2010). Immigrants and the Right to Stay. MIT Press.

Carens, J. (2010a). “The Most Liberal Citizenship Test is None at All”. In Bauböck, R. and Joppke, C., How Liberal Are Citizenship Tests? EUI Working Papers. RSCAS 2010/14. Available at: http://eudo-citizenship. 19-20.

Carr, C. L. (1988). Coercion and freedom. American Philosophical Quarterly, 25(1), 59-67.

Dahl, R. A. (1989). Democracy and its Critics. Yale University Press.

De Schutter, H., \& Ypi, L. (2015). The British Academy Brian Barry Prize Essay: Mandatory Citizenship for Immigrants. British Journal of Political Science, 45(2), 235-251. https://doi.org/10.1017/S0007123414000568

GLOBALCIT. (2017). Conditions for Electoral Rights 2017. Available at: http://globalcit.eu/conditions-for-electoral-rights/. Date accessed: 26 April 2018.

Goodin, R. E. (2007). Enfranchising all affected interests, and its alternatives. Philosophy \& public affairs, 35(1), 40-68. https://doi.org/10.1111/ j.1088-4963.2007.00098.x

Kees, G. and van Oers, R. (2010). "How Liberal tests are does not merely depend on their content, but also their effects". In Bauböck, R. and Joppke, C., How Liberal Are Citizenship Tests? EUI Working Papers. RSCAS 2010/14. http://eudocitizenship. 9-10.

Honohan, I. 2010 (June). Ius Soli Citizenship. Eudo Citizenship Policy, Briefing no 1, available at http://eudo-citizenship.eu/docs/IusSoli.pdf, [accessed 23 August 2016].

Joppke, C. (2010). “How Liberal Are Citizenship Tests?”. In Bauböck, R. and Joppke, C., How Liberal Are Citizenship Tests? EUI Working Papers. RSCAS 2010/14. http://eudo-citizenship. 1-4.

Kostakopoulou, D. (2010). "What Liberalism is Committed to and Why Current Citizenship Policies Fail this Test". In Bauböck, R. and Joppke, C., How Liberal Are Citizenship Tests? EUI Working Papers. RSCAS 2010/14. http://eudocitizenship. 15-18.

Kostakopoulou, D. (2008). The Future Governance of Citizenship. Cambridge University Press.

Kymlicka, W., \& Norman, W. (1994). Return of the citizen: A survey of recent work on citizenship theory. Ethics, 104(2), 352-381. https://doi.org/10.1086/293605

Kymlicka, W. (2006). Liberal Nationalism and Cosmopolitan Justice. In Post, R. ed. Another Cosmopolitanism. Oxford University Press, 128-144. 
López-Guerra, C. (2005). Should expatriates vote?.Journal of Political Philosophy, 13(2), 216-234. https://doi.org/10.1111/j.1467-9760.2005.00221.x

Lægaard, S. (2012). Naturalization, Desert, and Territories of Citizenship. In Beckman, L. and Erman, E. eds. Territories of Citizenship. Chippenham and Eastbourne: Palgrave Macmillan. 40-59.

Michalowski, I. (2010). "Citizenship Tests and Traditions of State Interference with Cultural Diversity”. In Bauböck, R. and Joppke, C., How Liberal Are Citizenship Tests? EUI Working Papers. RSCAS 2010/14. http://eudo-citizenship. 5-8.

Miller, D. (1988). The ethical significance of nationality. Ethics, 98(4), 647-662. https://doi.org/10.1086/292997

Nozick, R. (1969). Coercion. In Morgenbesser, S., Suppes, P. and White, M. eds. Philosophy, Science, and Method: Essays in Honor of Ernest Nagel. New York: St. Martin's Press, 440-472.

Orgad, L. (2010). "Five Liberal Concerns about Citizenship Tests”. In Bauböck, R. and Joppke, C., How Liberal Are Citizenship Tests? EUI Working Papers. RSCAS 2010/14. http://eudo-citizenship. 21-24.

Rubio-Marin, R. (1998). Equal Citizenship and the Difference that Residence Makes. In La Torre (ed.), European Citizenship: An Institutional Challenge. The Hage: Kluwer International.

Ryan, B. (2008). Integration Requirements: A New Model in Migration Law. Journal of Immigration, Asylum and Nationality Law,22(4), 303-316. http://hdl.handle.net/2381/28889

Seglow, J. (2009). Arguments for naturalisation. Political studies, 57(4), 788-804. https://doi.org/10.1111/j.1467-9248.2008.00768.x

UN General Assembly. (1948). Universal Declaration of Human Rights, 10 December 1948, 217 A (III), available at: http://www.refworld.org/docid/ 3ae6b3712c.html [accessed 26 April 2018]

UN General Assembly. (1966). International Covenant on Civil and Political Rights, 16 December 1966, United Nations, Treaty Series, vol. 999, p. 171, available at: http://www.refworld.org/docid/3ae6b3aa0.html [accessed 26 April 2018]

UN General Assembly. (1985). Declaration on the Human Rights of Individuals Who Are Not Nationals of the Country in Which They Live: resolution / adopted by the General Assembly, 13 December 1985, A/RES/40/144, available at: http://www.refworld.org/docid/3b00f00864.html [accessed 26 April 2018].

Francesco, V. (2004). The links of community according to Libertarianism and Communitarianism. In. Banús, E. and Llano, A. eds. Present and Future of Liberalism, Eunsa, Baranain, 521-533.

Waldrauch, H. (2005). "Electoral Rights for Foreign Nationals: A comparative Overview". Paper presented at the ESF/LESC-SCSS Exploratory Workshop: Citizens, Non-citizens and Voting Rights in Europe, School of Law, University of Edinburgh.

Walzer, M. (2008). The Distribution of Membership. Pogge, T. W. M., \& Moellendorf, D. eds. Global Justice: Seminal Essay, Global Responsibilities, Vol. I, St. Paul: Paragon House. 145-178.

Ziegler, R. (2017). Voting rights of refugees. Cambridge University Press. 